\title{
The Economic Development Impact To Environment Quality : Kuznet's Curve Hyphothesis and Non Linier Regression Approach
}

\author{
Rizka Zulfikar $^{1}$, Farida Yulianti ${ }^{1}$, Teguh Wicaksono ${ }^{1}$, Prihatini Ade Mayvita ${ }^{1}$ \\ ${ }^{1}$ Economic Faculty, Islamic University Of Kalimantan MAB Jalan Adhyaksa No. 22 Banjarmasin \\ Banjarmasin, South Kalimantan, Indonesia \\ Corresponding Author \\ Email : rizkazulfikar@gmail.com
}

\begin{abstract}
.
This study aims was to identify impact of economic development factors to the the environment quality by using Kuznet's Curve Hyphotesis and non linear regression. The determinants studied are indicators of economic development such as Gross Domestic Regional Income (GDRI) of the industrial sector, mining sector, agricultural/ plantation/ forestry/ fishery/ livestock sectors, poverty, unemployment and human development index (HDI). While the environmental quality indicators used are Water Quality Index (WQI), Air Quality Index (AQI) and Land Cover Quality Index (LCQI). The data used is secondary data from the Department of Environment, the Department of Energy and Mineral Resources, and also the Central Bureau of Statistics of South Kalimantan Province. Secondary data types used include WQI, AQI, LCQI, GDRI, poverty, unemployment and HDI data for the period 2006 -2020 . The method used in this study is descriptive quantitatively using Kuznet's Curve hypothesis and non linear regression. The final results obtained from this study include (1) The influence of economic development indicators on environmental quality is in accordance with Kuznet's Curve hypothesis and shows non-linear relationships. (2) Only the unemployment indicator is not identified non-linearly due to the adjusted value of $R$ Square $<0$ and the significance of the $>0.05$.
\end{abstract}

Keywords:Economic development, environmental quality, externalities, kuznet's curve, non-regression.

\section{INTRODUCTION}

The issue of the environment has now become a global issue which is the main concern of all countries in the world. In fact, the ultimate goal of the SDGS (Sustainable Development Goals) is about environmental protection and management. Demands in the global era with a series of challenges to be faced, such as development priority issues that emphasize the integration of environmentally sound development.

A problem in economic development that must be seriously considered is how to deal with tradeoffs between development and environmental conservation efforts [1]. Development that does not pay attention to these two aspects will cause problems in the future and the impact will not only on nature but will also have an impact on human life. The conventional development strategy pattern has become a series of challenges for policy makers related to massive exploration of natural resources and the environment. This exploration can result in extraction which can exceed the environmental carrying capacity threshold. In turn, this will lead to new problems in the environment itself, such as; increased pollution, prolonged drought, decreased load on water content, and decreased food content are real impacts that need to be considered more deeply [2].

Several researchers have tried to conduct research to obtain empirical evidence on the relationship between economic development and environmental quality in an area, as has been done by [3], [4], [5], [6] and [7]. However, the results obtained were different and did not provide certainty about the relationship between economic development and the environmental quality index.

Based on the above background and to add empirical evidence, it is necessary to have further studies to determine the impact (environmental externalities) caused by economic development (GDRI, unemployment and the Human Development Index) with a case study in South Kalimantan province. This study uses the Kuznet's Curve hypothesis approach as conducted by [3], [4], [5], [6] and [7]. 
Economic development is seen as a development process that occurs continuously and dynamically [8]. Economic development is also seen as a structurally marked transformation process [9]. The change occurred as a result of economic activity [10] and there are factors that influence the changing role of the economic sector in efforts to establish national income [9].Economic development can also be considered a spontaneous and disconnected change - discontinuous in the circular current channel which is a disruption to the balance that always changes and changes the state of the previous balance [11].Economic development is the main support for the success of a country [12], but on the other hand development is also a big problem that must be faced especially the impact of the process of development activities on the quality of the environment [13].

Kuznets Curve Environmental Theory states that cases in developing countries over time, technological advances can damage natural and environmental sustainability [3]. Meanwhile, in developed countries over time technological advances can improve environmental sustainability [14]. This theory is known as the first theory to describe how the relationship between economic growth rates and environmental degradation [3]. This theory states that when a country's income is still relatively low, then the attention of the country - both in terms of production of investment that can encourage the increase in income by putting aside environmental problems [3]. As a result revenue growth will be followed by pollution levels and will then decrease with continued growth [15].

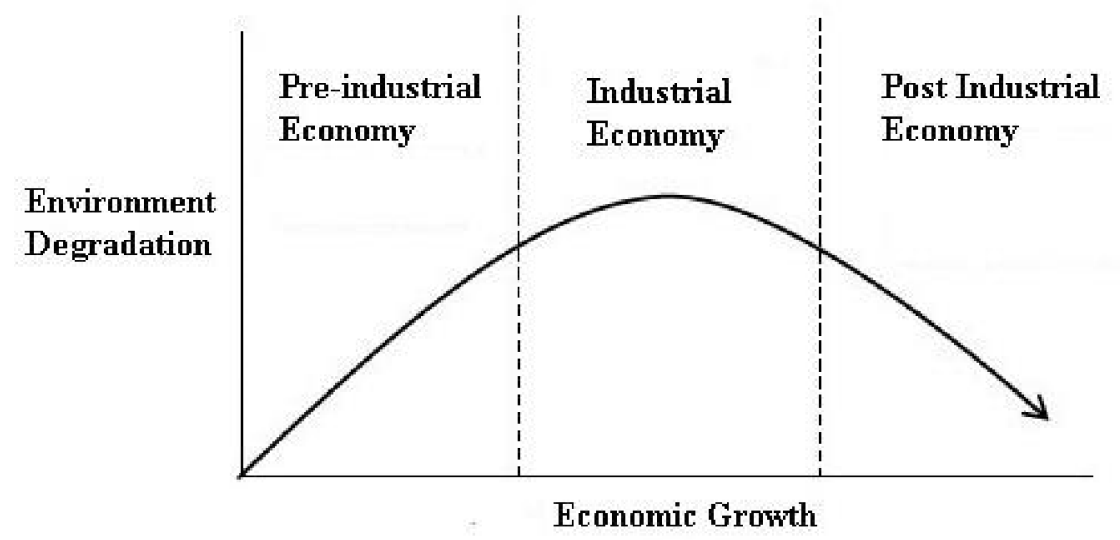

Fig 1. Environmental Kuznet Curve

Environmental Kuznet Curve is divided into three stages, among others; first, the beginning of the economic development process will be followed by environmental damage called pre-industrial economic; second, the industrial economic stage, and third, the post-industrial economic or post-industrial stage. Initially, industrialization started from a small industry and then developed into a large industry. This movement will increase natural resources and increase environmental degradation [16]. After that, industrialization will expand its role in the formation of domestic national products. This happens in the second phase, along with investment that encourages economic transformation from the agricultural sector to the industrial sector [15]. In the third phase, there is a movement of economic transformation from the industrial sector to the service sector. This movement will be followed by a decrease in air pollution in line with the increase in revenue [17]. Along with that, the demand for environmental quality goes hand in hand with increased revenue. People began to be able to pay environmental losses arising from economic activities [15]. The results of this research can later be used by policy makers in formulating economic development activities that do not damage the quality of the environment in South Kalimantan province.

\section{METHOD AND RESEARCH DATA}

This research was conducted in South Kalimantan Province, with the research period starting from December 2020 to March 2021. The implementation of this research will be carried out according to the following stages:

a) Collection of secondary data from the Department of Environment, Department of Energy and Mineral Resources, and Central Bureau of Statistics South Kalimantan Province.

b) Calculating the Environmental Quality Index (EQ ) with the following formula:

$$
\mathrm{EQ}=30 \% \mathrm{WQI}+30 \% \mathrm{AQI}+40 \% \mathrm{LCQI} \text {. }
$$


Which is :

WQI = Water Quality Index

AQI $\quad=$ Air Quality Index

LCQI = Land Cover Quality Index

c) Data analysis using Kuznet's Curve Hypothesis and non-linear regression

d) Determine the non-linear regression equation model for each indicator of economic development on environmental quality.

The data used in this research is secondary data such as Gross Domestic Regional Income(GDRI) for industrial sector, mining sector, agricultural / plantation / fisheries / livestock / forestry sector, and transportation sector, poverty, unemployment, the Human Development Index (HDI), WQI, AQI and LCQI for the period from 2006 to 2019 (14 years).

Table 1.Data Of Economic Development Indicators (GDRI, Poverty Rate, Unemployment and HDI) South Kalimantan Province (2006 - 2019)

\begin{tabular}{|c|c|c|c|c|c|c|c|}
\hline \multirow[t]{2}{*}{ Year } & \multicolumn{4}{|c|}{ GDRI (Million Rupiah) } & \multirow[t]{2}{*}{ Poverty } & \multirow{2}{*}{$\begin{array}{c}\begin{array}{c}\text { Unemploy- } \\
\text { ment }\end{array} \\
(\%)\end{array}$} & \multirow{2}{*}{$\begin{array}{r}\text { HDI } \\
(\%)\end{array}$} \\
\hline & Industry & Mining & Agriculture,etc & $\begin{array}{c}\text { Transpor- } \\
\text { tation }\end{array}$ & & & \\
\hline 2006 & $10,520,739$ & $24,833,258$ & $12,153,833$ & $4,161,347$ & 156.16 & 4.26 & 53.72 \\
\hline 2007 & $10,959,103$ & $25,867,978$ & $12,660,242$ & $4,334,737$ & 162.67 & 4.44 & 55.96 \\
\hline 2008 & $11,415,732$ & $26,945,810$ & $13,187,752$ & $4,515,351$ & 169.44 & 4.63 & 58.30 \\
\hline 2009 & $11,891,388$ & $28,068,552$ & $13,737,242$ & $4,703,490$ & 176.50 & 4.82 & 60.72 \\
\hline 2010 & $12,386,862$ & $29,238,075$ & $14,309,627$ & $4,899,469$ & 183.86 & 5.02 & 63.25 \\
\hline 2011 & $12,902,981$ & $30,456,328$ & $14,905,862$ & $5,103,614$ & 191.52 & 5.23 & 65.89 \\
\hline 2012 & $13,998,493$ & $31,769,406$ & $15,769,427$ & $5,715,866$ & 190.69 & 5.25 & 66.68 \\
\hline 2013 & $14,970,914$ & $33,385,624$ & $16,861,733$ & $6,501,454$ & 183.07 & 3.79 & 67.17 \\
\hline 2014 & $16,563,934$ & $34,434,083$ & $18,752,977$ & $7,491,669$ & 182.88 & 3.80 & 67.63 \\
\hline 2015 & $18,599,681$ & $31,304,930$ & $20,559,267$ & $8,547,115$ & 198.44 & 3.43 & 68.38 \\
\hline 2016 & $20,732,755$ & $30,650,347$ & $21,793,561$ & $9,387,063$ & 195.70 & 3.90 & 69.05 \\
\hline 2017 & $22,951,176$ & $33,121,192$ & $23,171,076$ & $10,345,466$ & 193.92 & 4.77 & 69.65 \\
\hline 2018 & $24,081,132$ & $35,446,489$ & $24,470,163$ & $11,387,160$ & 189.03 & 4.50 & 70.17 \\
\hline 2019 & $24,635,694$ & $33,808,885$ & $25,953,255$ & $12,503,124$ & 192.48 & 4.31 & 70.72 \\
\hline
\end{tabular}

While the WQI, AQI and LCQI obtained is presented in Table 2 below.

Tabel 2. Data Of WQI, AQI and LCQI South Kalimantan Province (2006 - 2019)

\begin{tabular}{ccccc}
\hline Year & WQI & AQI & LCQI & EQ \\
\hline 2006 & 28.54 & 81.12 & 37.82 & 48.03 \\
2007 & 29.73 & 84.50 & 39.39 & 50.03 \\
2008 & 30.97 & 88.02 & 41.04 & 52.11 \\
2009 & 32.26 & 91.69 & 42.75 & 54.28 \\
2010 & 33.60 & 95.51 & 44.53 & 56.54 \\
2011 & 35.00 & 99.49 & 46.38 & 58.90 \\
2012 & 53.26 & 77.46 & 43.81 & 56.74 \\
2013 & 46.16 & 81.83 & 43.66 & 55.86 \\
2014 & 44.00 & 88.35 & 44.51 & 57.51 \\
2015 & 46.95 & 87.6 & 44.24 & 58.06 \\
2016 & 43.78 & 85.6 & 50.64 & 59.07 \\
2017 & 73.57 & 89.02 & 51.51 & 69.38 \\
2018 & 75.8 & 87.75 & 49.29 & 68.78 \\
2019 & 73.18 & 88.78 & 49.48 & 68.38 \\
\hline
\end{tabular}

Each data on economic development indicators is then plotted and compared with the Kuznet's Curve hypothesis and presented in Figures $2-8$. 


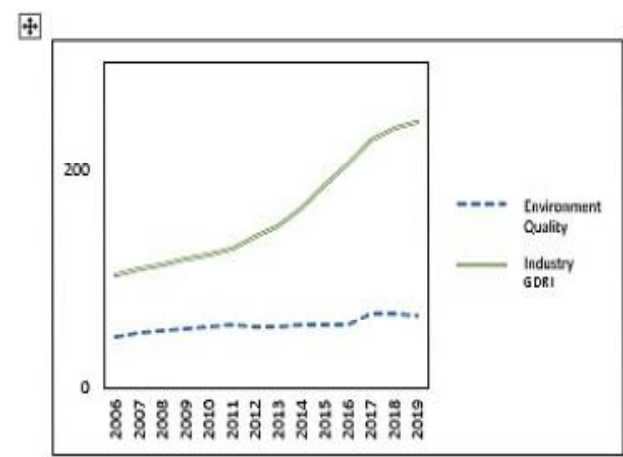

Figure 2. EQ and Industry GDRI

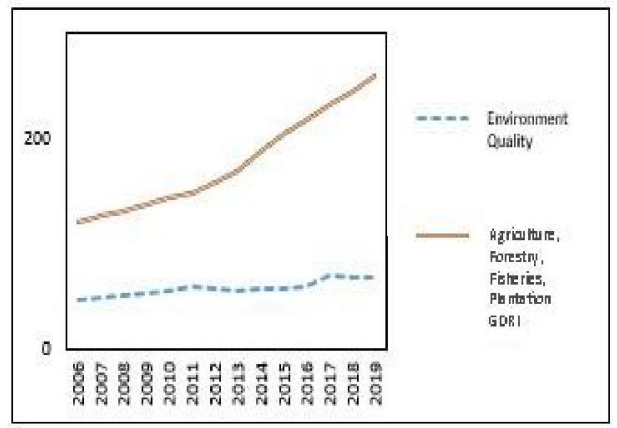

Figure 4. EQ and Agriculture/Forestry/

Fisheries/Livestocks/Farming GDRI

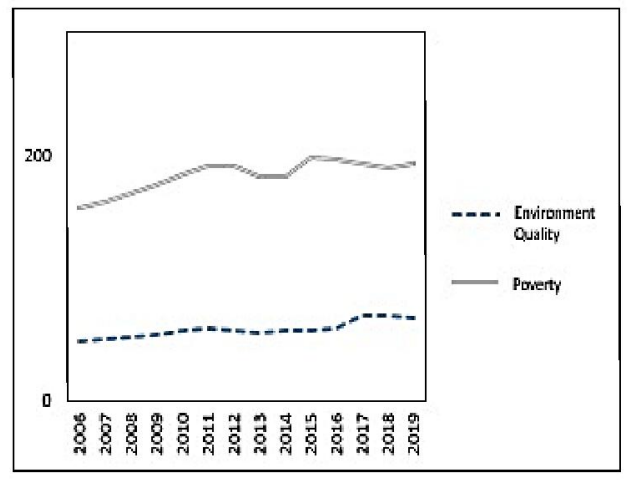

Figure 6. EQ and Poverty

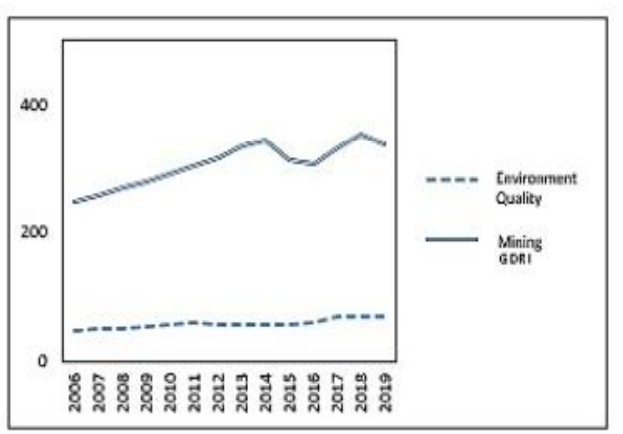

Figure 3. EQ and Mining GDRI

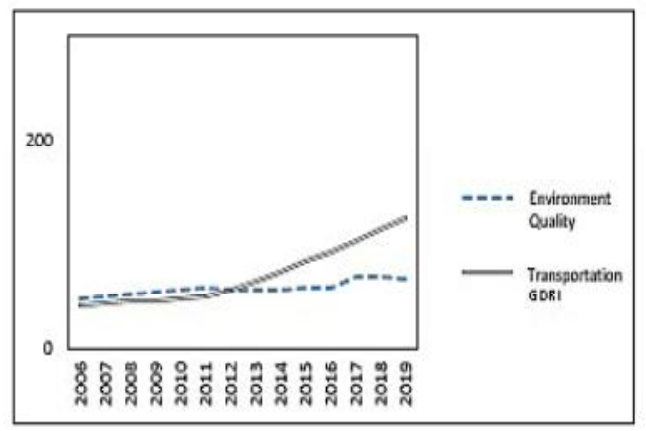

Figure 5. EQ and Transportation GDRI

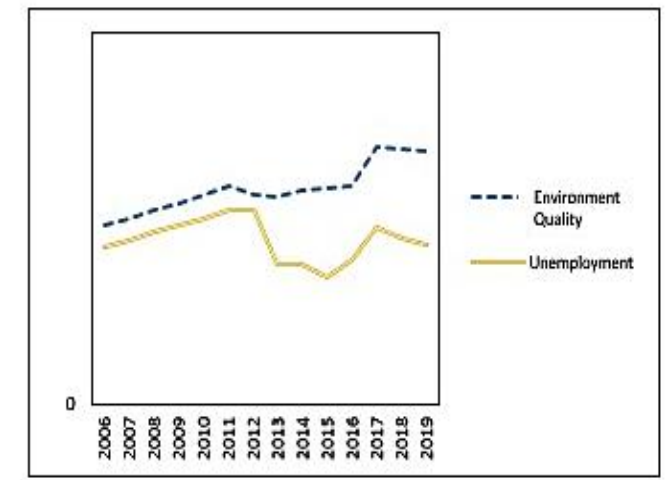

Figure 7. EQ and Unemployment

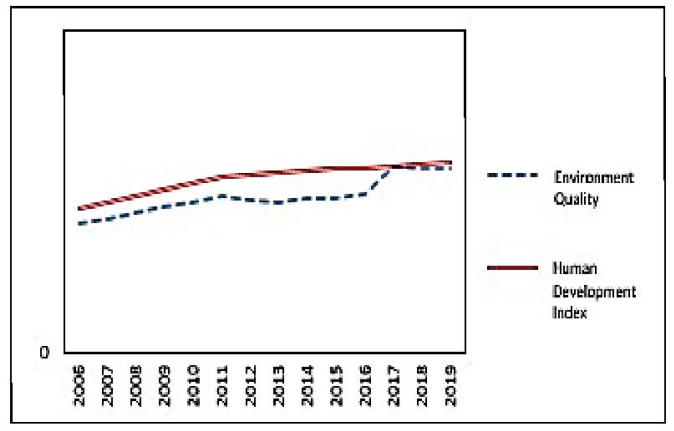

Figure 8. EQ and human Development Index 
Furthermore, in this study phase determining the best model for the relationship between EQ with all Indicator economic development is done by using non-linear regression analysis with several models such as logarithmic, quadratic, cubic, and exponential curve $\mathrm{S}$. The best model is determined based on the value of the Largest Adjusted R and Significance Value $<0.005$

\section{RESULT AND DISCUSSION}

The relationship between environmental quality and GDRI in the Industrial sector of South Kalimantan Province shows a relationship in accordance with the Kuznet's Curve hypothesis which can be stated that along with the increase in GDRI the Industrial sector will initially reduce the quality of the environment (conditions in 2006 - 2017), but up to a certain point (conditions in 2018 2019), GDRI continues to increase and is followed by environmental improvement activities which are marked by decreasing environmental damage in South Kalimantan Province. The existence of industrial activities intends to process and utilize natural resources, but in fact the use of these natural resources is excessive to produce excess material as well, this can reduce the carrying capacity of the environment and even have a negative effect on human survival [18].

In the mining sector, the relationship between environmental quality and GDRI in the Mining sector of South Kalimantan Province shows a relationship that is not proven. In the Mining Sector the Environmental Kuznets Curve Hypothesis is not proven. The relationship between the mining sector and the Environmental Quality Index resembles a sloping U letter. At the beginning of the development process in this sector, it was followed by a decrease in environmental quality to a certain extent with a relatively small income. When at a certain point, income increases but without being followed by a decrease in the quality of the environment. In this sector, there are negative externalities, which are indicated by the number of disasters. In general, the impact of mining on the environment is a decrease in land productivity, increased soil density, erosion and sedimentation, land movement or landslides, disruption of flora and fauna, disruption of public health and an impact on micro-climate change [19], [20].

Increased production which in turn will increase income in the agricultural, forestry, fishery and plantation sectors initially without paying attention to environmental aspects. Therefore, the relationship of Environmental Quality Index of the sectors of agriculture, forestry, fisheries and plantation resembles $a U$ inverted sloping.

At the beginning of the economic development process in the agricultural, forestry, fishery and plantation sectors, it will be followed by an increase in income accompanied by environmental damage and at a certain point the increase in income is accompanied by a demand for environmental quality and in turn when this boundary point is reached, the activities at This sector has been accompanied by a very slow improvement in environmental quality. The impact of agricultural activities on the environment varies greatly from water pollution, climate change, to genetic pollution. Solutions to avoid this impact range from implementing sustainable agriculture to returning to subsistence farming systems [21] .

The relationship between the Environmental Quality Index and the transportation sector resembles a sloping inverted $U$ - . At the beginning of the economic development process in the transportation sector it will be followed by an increase in income accompanied by environmental damage and at a certain point the increase in income is accompanied by a demand for environmental quality and in turn when this boundary point is reached, activity in this sector is accompanied by a very slow improvement in environmental quality.

The transportation sector is a major source of greenhouse gas emissions [22]. It is estimated that 30 percent of greenhouse gases on a national scale are directly linked to transportation and in some areas, the proportion is even higher [21]. Other environmental impacts of the transport system include traffic congestion and expansion of car-oriented cities, which can deplete natural habitats and agricultural land. By reducing transportation emissions globally, it is estimated that there will be significant positive effects on the earth's air quality, acid rain, smog, and climate change [23]. 
Poverty and environmental damage tend to be negatively correlated. Poverty occurs because of environmental damage or otherwise the environment is damaged due to poverty in the surrounding area. This causal relationship can continue to form a cycle that does not end. In such conditions, poverty will get worse and the environment will be more and more damaged. The longer the condition lasts, the more chronic Keadaa $\mathrm{n}$ her, so that the poverty rate will change is not linear. The threat of negative impacts from climate change is one of the factors that complicates efforts to alleviate the poor [24]. Most poor countries are oriented towards rural and traditional agriculture, so they are very vulnerable to climate change. Without proper anticipation and mitigation, poverty can actually increase [25].

Improved economic development growth will open jobs and reduce unemployment, and along with economic development growth, environmental damage will also increase. However, at a certain point, economic growth will slow down accompanied by improving environmental quality. In this condition, the unemployment rate will also slow down.

Along with the increase in economic development, it will increase the human development index which consists of the quality of life index, the infant mortality rate and the literacy rate. And just like the Environmental Kuznets curve, at some point, economic growth will slow down and the human development index numbers will slow down. A relatively high level of human development will affect the performance of economic growth through the capabilities of the population and the consequence is an increase in the productivity and creativity of the community. With increased productivity and creativity, residents can absorb and manage resources that are important for economic growth and pay more attention to the environment [26].

Determination of the best model for the relationship between economic development indicators and environmental quality is carried out by non-linear regression with a summary of the analysis results presented in table 3 below.

Table 3. Summary of Non-Linear Regression Results

\begin{tabular}{|c|c|c|c|c|c|c|c|c|c|c|}
\hline No & Relation & ship & Model & $\begin{array}{c}\text { Ad } \\
\mathrm{j} \cdot \mathrm{R} \\
\mathrm{Sq} \\
\mathrm{ua} \\
\text { re }\end{array}$ & $\boldsymbol{\beta}_{0}$ & $\beta_{1}$ & $\boldsymbol{\beta}_{2}$ & $\boldsymbol{\beta}_{3}$ & $\mathbf{F}$ & Sig. \\
\hline 1 & Industry & $\begin{aligned} \rightarrow & \mathrm{E} \\
& \mathrm{Q}\end{aligned}$ & $\begin{array}{l}\text { Logarit } \\
\text { mic }\end{array}$ & $0.81 !$ & $\begin{array}{l}- \\
1516 . \overline{7} \\
3\end{array}$ & 413.8 & & & $\begin{array}{c}59.8 \\
2\end{array}$ & 0.00 \\
\hline 2 & Mining & $\begin{aligned} \rightarrow & \mathrm{E} \\
& \mathrm{Q}\end{aligned}$ & Cubic & 0.73 & $\begin{array}{l}- \\
511.71\end{array}$ & 18.90 & 2.75 & $\begin{array}{l}- \\
0.001\end{array}$ & $\begin{array}{c}18.9 \\
0\end{array}$ & 0.00 \\
\hline 3 & $\begin{array}{l}\text { Agricultur } \\
\mathrm{e},\end{array}$ & $\begin{array}{r}\rightarrow \mathrm{E} \\
\mathrm{Q}\end{array}$ & $\begin{array}{l}\text { Logarit } \\
\text { mic }\end{array}$ & $0.80^{\prime}$ & $\begin{array}{l}- \\
1355.7 \\
3\end{array}$ & $\begin{array}{c}377.9 \\
3\end{array}$ & & & $\begin{array}{c}55.4 \\
4\end{array}$ & 0.00 \\
\hline 4 & $\begin{array}{l}\text { Transp. } \\
\text { GDRI }\end{array}$ & $\begin{array}{r}\rightarrow \\
\mathrm{E} \\
\mathrm{Q}\end{array}$ & $\begin{array}{l}\text { Logarit } \\
\text { mic }\end{array}$ & 0.78 & $\begin{array}{l}- \\
845.92\end{array}$ & $\begin{array}{c}226.0 \\
7\end{array}$ & & & $\begin{array}{c}47.3 \\
7\end{array}$ & 0.00 \\
\hline 5 & Poverty & $\begin{array}{r}\rightarrow \\
\mathrm{E} \\
\mathrm{Q}\end{array}$ & Cubic & $0.89^{\circ}$ & $\begin{array}{l}- \\
305.94\end{array}$ & 11.77 & $\begin{array}{l}113.0 \\
1\end{array}$ & $\begin{array}{l}- \\
0.001\end{array}$ & $\begin{array}{c}57.6 \\
0\end{array}$ & 0.00 \\
\hline 6 & $\begin{array}{l}\text { Unemploy } \\
\text { ment }\end{array}$ & $\begin{aligned} \rightarrow & \mathrm{E} \\
& \mathrm{Q}\end{aligned}$ & $\begin{array}{l}\text { Unidentf } \\
\text { ied }\end{array}$ & - & - & - & - & - & $\begin{array}{c}< \\
0.31\end{array}$ & $\begin{array}{c}> \\
0.05\end{array}$ \\
\hline 7 & HDI & $\begin{aligned} \rightarrow & \mathrm{E} \\
& \mathrm{Q}\end{aligned}$ & Cubic & 0.91 & $\begin{array}{l}- \\
110.90\end{array}$ & 4.134 & 89.58 & 0.000 & $\begin{array}{l}74.3 \\
9\end{array}$ & 0.00 \\
\hline
\end{tabular}

Based on the results of the non-linear regression presented in table 3, it can be seen that the relationship between environmental quality and GDRI Industry can be described by a logarithmic model 
(Figure 9) which gives the largest Adjusted R Square value (0.819) with a calculated F value (59.822) $>\mathrm{F}$ Table (0.306) ) and the significance $<0.05$, it can be said that the GDRI Industry has an effect of $81.9 \%$ on EQ while the remaining $18.1 \%$ is influenced by other factors. Based on the results of the non-linear regression above, the relationship between EQ and GDRI Industry can be expressed by the following equation:

$$
\begin{gathered}
\mathrm{EQ}=-1516.725+413.796 \ln (\text { Industry GDRI })+\varepsilon \\
\text { Industry GDRI }
\end{gathered}
$$

\section{Industry GDRI}

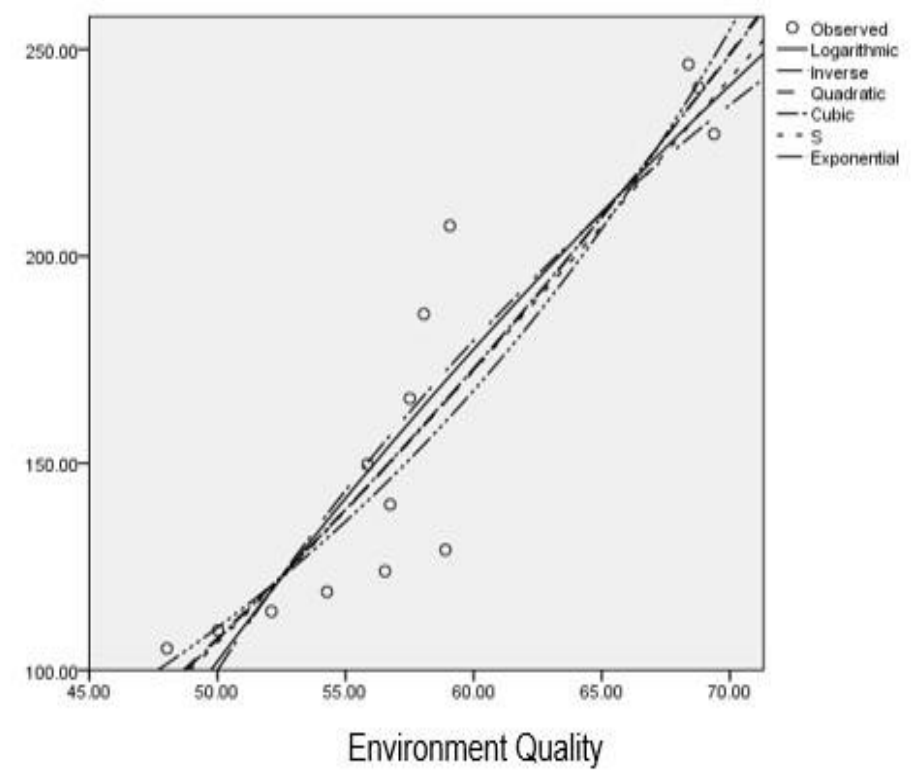

Fig 9. Non linier regression EQ and Industry GDRI

For the mining sector, the relationship between environmental quality can be described by the cubic model (Figure 10) because the cubic model provides the largest Adjusted R Square value (0.734) with a calculated F value (18.895) $>$ F Table (0.306) and a significance $<0.05(0.000)$ if compared to other models. So it can be said that the mining GDRI has an effect of $73.4 \%$ on EQ while the remaining $26.6 \%$ is influenced by other factors. Based on the results of the non-linear regression above, the relationship between EQ and mining GDRI can be expressed by the following equation:

$\mathrm{EQ}=-511.713+18.898$ Mining GDRI +2.747 Minig GDRI ${ }^{2}-0.001$ Mining GDRI $^{3}+\varepsilon$

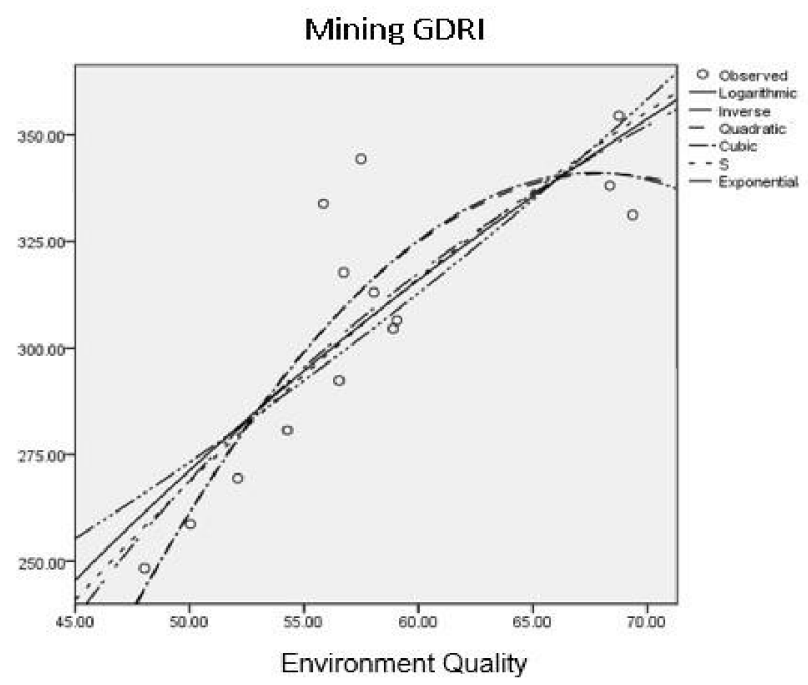

Fig 9. Non linier regression EQ and Industry GDRI 
For the Agriculture, etc sector, according to Table 3, it can be seen that the logarithmic model provides the largest Adjusted R Square value (0.807) compared to other models (Figure 11). From the adjusted R Square value, it can be said that the PKPP GDRI sector has an influence of $80.7 \%$ on EQ, while the remaining $19.3 \%$ is influenced by other factors. The relationship between EQ and the Agriculture GDRI sectors can be expressed by the logarithmic equation as follows:

$$
\mathrm{EQ}=0.807-1355.734 \ln (\text { Agriculture,etc GDRI })+\varepsilon \ldots
$$

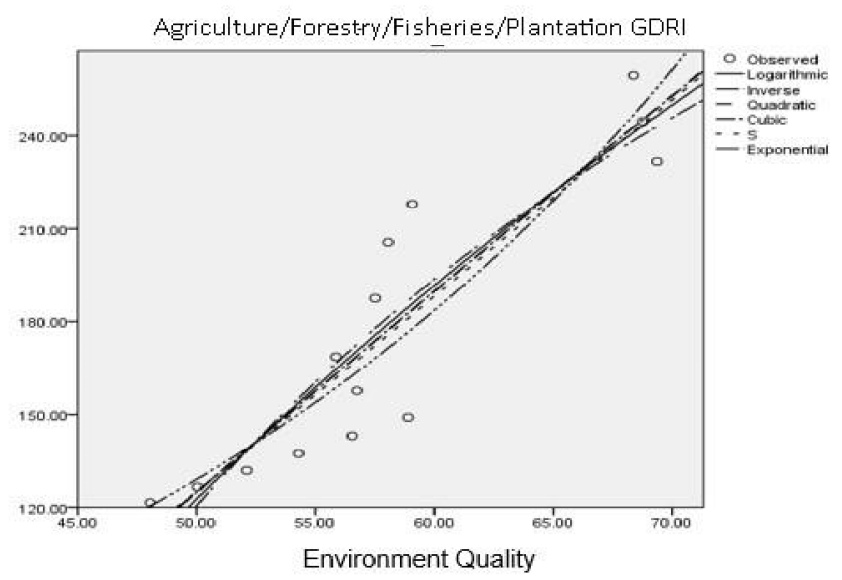

Fig 11. Non linier regression EQ and Agriculture, etc GDRI

According to table 3, it can be seen that the relationship between GRDB transportation and environmental quality can be described by a logarithmic model (Figure 12) where this model is able to provide the largest Adjusted R Square value (0.781) with a calculated $F$ value (47.366) $>$ F Table (0.306) and a significance $<0.05(0.000)$ when compared to other models. So it can be said that the transportation sector GDRI has an effect of $78.1 \%$ on EQ while the remaining $21.8 \%$ is influenced by other factors. then the relationship between EQ and the mining GDRI can be stated by the following equation:

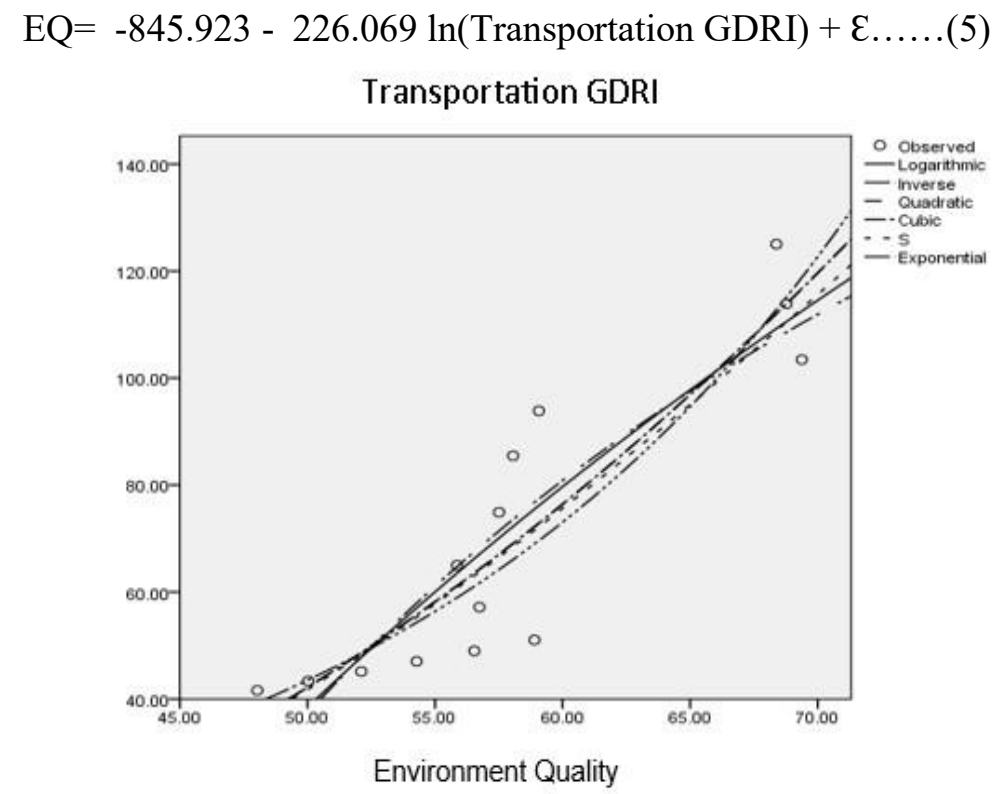

Figure 12. Non linier regression EQ and Transportation GDRI

According to table 3, the relationship between poverty rates and environmental quality can be described by the cubic model (Figure 13) because it provides the largest Adjusted R Square value (0.897) with a calculated $F$ value $(57.92)>F$ Table $(0.306)$ and a significance $<0.05(0.000)$ if compared to other models. So 
it can be said that the poverty rate has an influence of $89.7 \%$ on EQ while the remaining $10.3 \%$ is influenced by other factors. The relationship between EQ and poverty can be expressed by the cubic equation as follows:

$$
\mathrm{EQ}=-305.939+11.767 \text { Poverty }+113.005 \text { Poverty }^{2}-0.001 \text { Poverty }^{3}+\varepsilon \ldots(6)
$$

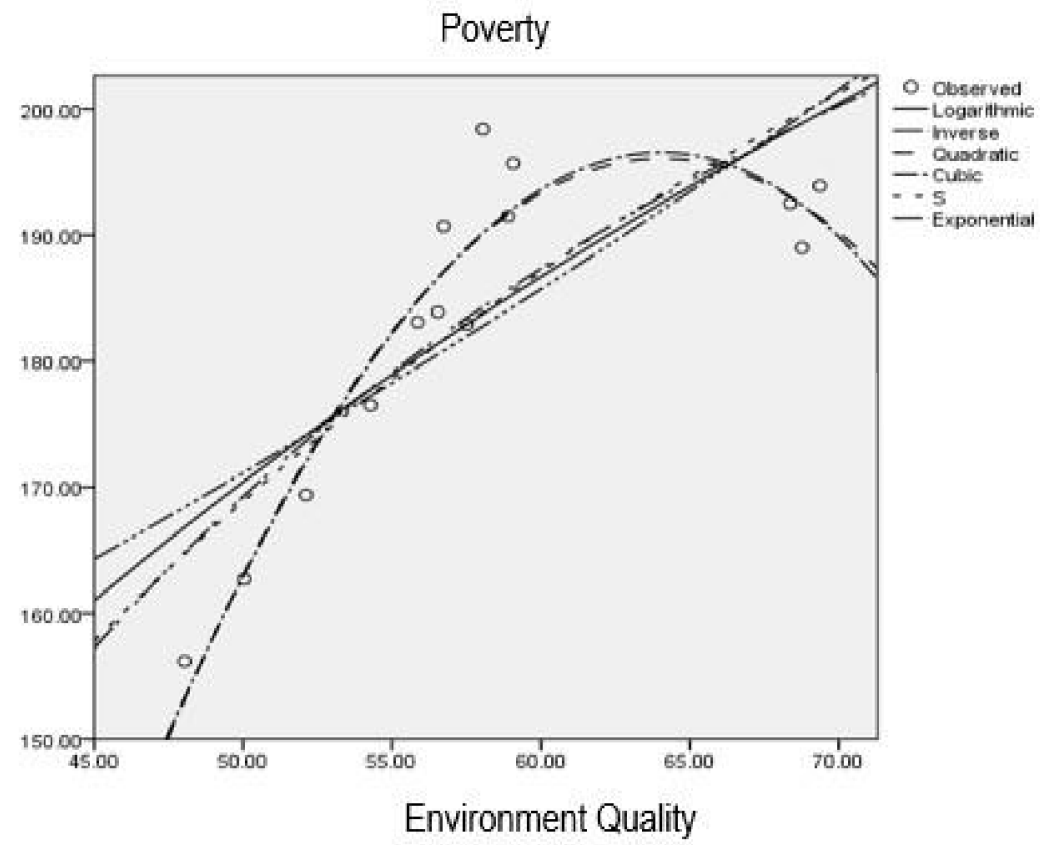

Fig 13. Non linier Regression EQ and Poverty

According to table 3, the relationship between EQ and unemployment cannot be described by all possible non-linear models (Figure 14) because the adjusted $\mathrm{R}$ value is too small $(<0.00)$, the calculated $\mathrm{F}$ value $<F$ table value $(0.306)$ and the overall significance of the model is $<0.05$. So it can be said that the unemployment rate has no effect on EQ.

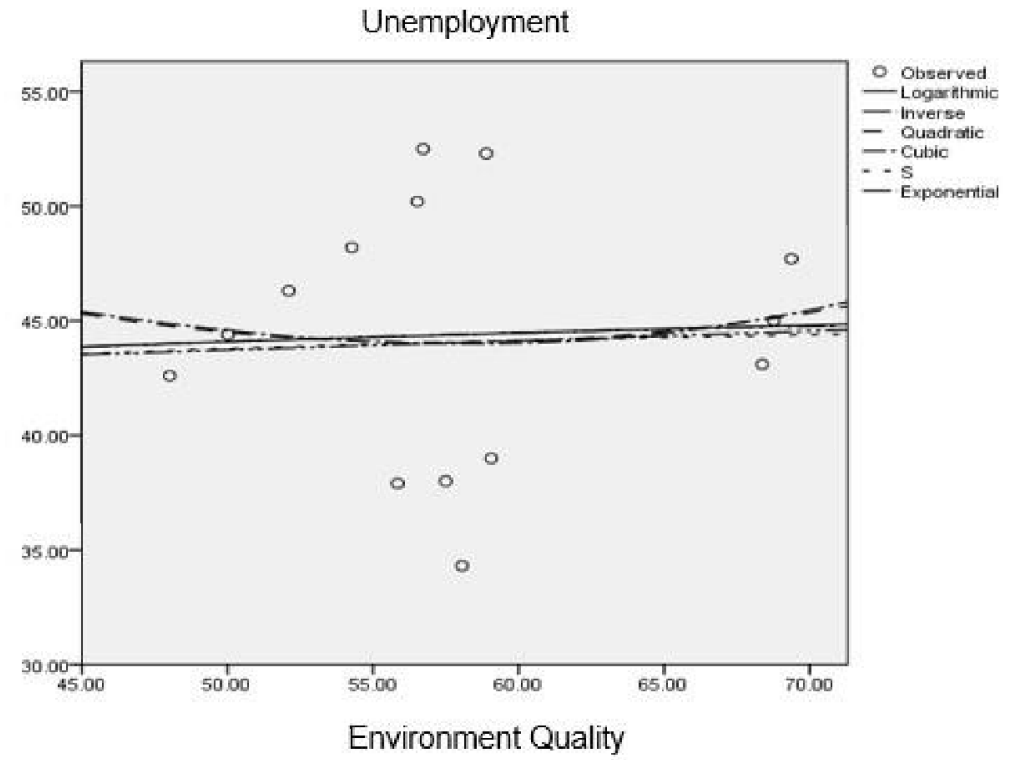

Fig 14. Non linier Regression EQ and Unemployment

For the relationship between EQ and HDI, based on the results of non-linear regression according to Table 3, it can be seen that the cubic model (Figure 15) provides the largest Adjusted R Square value (0.919) compared to other models, so that the relationship between EQ and the human development index can be expressed by the cubic equation. as follows : 


$$
\mathrm{EQ}=-110.889+4.134 \mathrm{HDI}+89.581 \mathrm{HDI}^{2}+0.000 \mathrm{HDI}^{3}++\varepsilon
$$

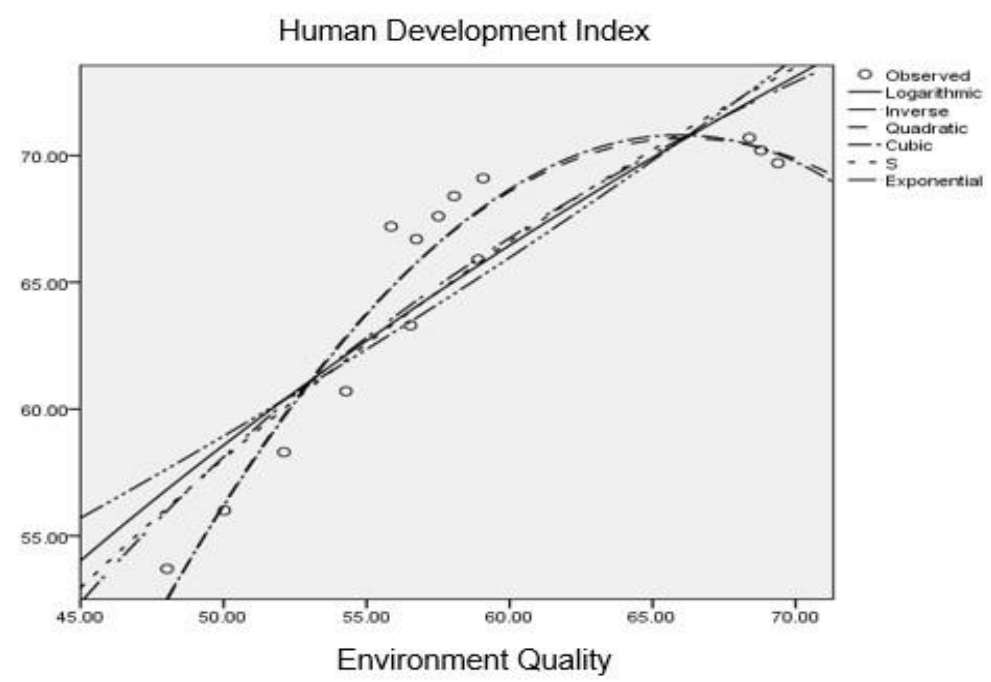

Figure 15. Non linier Regression EQ and Human Development Index

\section{CONCLUSION}

In accordance with our research results, the relationship between environmental quality and economic indicators, GDRI Industry has a significant effect on environmental quality with a logarithmic relationship model ( EQ $=-1516,725+413,796 \ln ($ GDRI Industri) $+\varepsilon)$. For GDRI Mining has a significant effect on environmental quality with the cubic relationship model $\left(\mathrm{EQ}=-511,713+18,898 \mathrm{EQ}+2,747 \mathrm{EQ}^{2}\right.$ $\left.0.001 \mathrm{EQ}^{3}+\varepsilon\right)$. For GDRI Agriculture / Forestry / Fisheries / Plantation a significant effect on environmental quality with a logarithmic relationship model $(\mathrm{EQ}=0.807-1355.734 \ln ($ GDRI PKPP) + $\varepsilon)$. Furthermore, GDRI Transportation has a significant effect on environmental quality with a logarithmic relationship model ( $\mathrm{EQ}=-845,923-226,069$ ln (GDRI Transportation) $+\varepsilon$ ). Likewise, the Poverty indicator has a significant effect on environmental quality with the cubic relationship model $\left(\mathrm{EQ}=-305,939+11,767\right.$ Poverty $+113,005$ poverty $^{2}-0.001$ poverty $\left.^{3}+\varepsilon\right)$. However , the unemployment indicator does not have a significant effect on environmental quality, because the significance value is $>0.05$ and the relationship model cannot be identified. The last indicator is the Human Development Index which has a significant effect on environmental quality with a cubic relationship model $\left(\mathrm{EQ}=\mathrm{EQ}=-110,889+4,134 \mathrm{IPM}+89,581 \mathrm{IPM}^{2}+0,000 \mathrm{IPM}^{3}++\varepsilon\right)$.

U ntuk implementation of future studies, could be followed up by identifying the relationship between indicators of economic development with environmental kualittas using more complex methods such as the use of structual equation modeling. In order to make the relationship between the two variables more clearly visible, it can be used as empirical evidence for the relationship between these two variables.

\section{ACKNOWLEDMENT}

This research was carried out by support and facilities from LPPM- Islamic University of Kalimantan Muhammad Arsyad Al Banjari Banjarmasin using APBU Uniska funds for 2020/2021.

\section{REFERENCES}

[1]. Drews, S., \& van den Bergh, J. C. (2017). Scientists' views on economic growth versus the environment: a questionnaire survey among economists and non-economists. Global Environmental Change, 46, 88-103.

[2]. Zulfikar, R. \& P.A. Mayvita (2019). Pengantar Green Economy. Cetakan Pertama, Deepublish-Yogyakarta

[3]. Özokcu, S., \& Özdemir, Ö. (2017). Economic growth, energy, and environmental Kuznets curve. Renewable and Sustainable Energy Reviews, 72, 639-647. 
[4]. Febriana, S., \& Herman Cahyo Diartho, N. I. (2019). Hubungan pembangunan ekonomi terhadap kualitas lingkungan hidup di provinsi jawa timur. Jurnal Dinamika Ekonomi Pembangunan, 2(2).

[5]. Churchill, S. A., Inekwe, J., Ivanovski, K., \& Smyth, R. (2018). The environmental Kuznets curve in the OECD: 1870-2014. Energy Economics, 75, 389-399.

[6]. Dogan, E., \& Inglesi-Lotz, R. (2020). The impact of economic structure to the environmental Kuznets curve (EKC) hypothesis: evidence from European countries. Environmental Science and Pollution Research, 27(11), 12717-12724.

[7]. Suki, N. M., Sharif, A., Afshan, S., \& Suki, N. M. (2020). Revisiting the Environmental Kuznets Curve in Malaysia: The role of globalization in sustainable environment. Journal of Cleaner Production, 264, 121669.

[8]. Hailemariam, A., Dzhumashev, R., \& Shahbaz, M. (2020). Carbon emissions, income inequality and economic development. Empirical Economics, 59(3), 1139-1159.

[9]. Malizia, E., Feser, E. J., Renski, H., \& Drucker, J. (2020). Understanding local economic development. Routledge.

[10]. Cheng, C. Y. (2019). China's Economic Development: Growth and Structural Change. Routledge.

[11]. Kahn, H. (2019). World economic development: 1979 and beyond. Routledge.

[12]. Barnes, S. J. (2019). Understanding plastics pollution: The role of economic development and technological research. Environmental Pollution, 249, 812-821.

[13]. Breza, E., Chandrasekhar, A., Golub, B., \& Parvathaneni, A. (2019). Networks in economic development. Oxford Review of Economic Policy, 35(4), 678-721.

[14]. Bekhet, H. A., Othman, N. S., \& Yasmin, T. (2020). Interaction Between Environmental Kuznet Curve and Urban Environment Transition Hypotheses in Malaysia. International Journal of Energy Economics and Policy, 10(1), 384.

[15]. Zulfa, E., \& Resha, M. (2020). Economic determinants of carbon dioxide emissions: A proof of the environmental kuznet curve hypothesis in Asia. TEST Engineering and Management, 82, 6877-6885.

[16]. Robbi, I., Ismail, M., \& Hoetoro, A. (2020, June). Environmental Degradation in Indonesia 1969-2016. In 23rd Asian Forum of Business Education (AFBE 2019) (pp. 352-356). Atlantis Press.

[17]. Pratama, Y. P. (2020). KONSENSUS KEMITRAAN GLOBAL PBB (MDGs \& SDGs), HIPOTESIS ENVIRONMENTAL KUZNET CURVE (EKC), DAN DEGRADASI KUALITAS UDARA DI INDONESIA PERIODE 1980-2018. Diponegoro Journal of Economics, 9(4).

[18]. Ridwan, I. R. (2010). Dampak industri terhadap lingkungan dan sosial. Jurnal Geografi Gea, 7(2).

[19]. Fachlevi, T. A., Putri, E. I. K., \& Simanjuntak, S. M. (2015). Dampak dan Evaluasi Kebijakan Pertambangan Batubara di Kecamatan Mereubo. RISALAH KEBIJAKAN PERTANIAN DAN LINGKUNGAN Rumusan Kajian Strategis Bidang Pertanian dan Lingkungan, 2(2), 170-179.

[20]. Fitriyanti, R. (2018). Pertambangan Batubara: Dampak Lingkungan, Sosial dan Ekonomi. Jurnal Redoks, 1(1).

[21]. Gupito, K. R., \& KODOATIE, J. M. (2012). Keterkaitan GDRI Perkapita Dari Sektor Industri, Transportasi, Pertanian dan Kehutanan Terhadap Kualitas Lingkungan Diukur Dari Emisi Co (Studi kasus di: 30 Kab/Kota Provinsi Jawa Tengah Tahun 2009-2010) (Doctoral dissertation, Fakultas Ekonomika dan Bisnis).

[22]. Gusnita, D. (2010). Green transport: transportasi ramah lingkungan dan kontribusinya dalam mengurangi polusi udara. Berita Dirgantara, 11(2).

[23]. Aly, S. H. (2015). Emisi Transportasi. Penebar Plus+. Jakarta

[24]. Sudantoko, H. D., \& Mariyono, J. (2010). Tinjauan Teoritis Pembangunan Pedesaan Yang Berkelanjutan: Pengentasan Kemiskinan dan Perbaikan Kualitas Lingkungan. JEJAK: Jurnal Ekonomi dan Kebijakan, 3(2).

[25]. Ridena, S. (2021). KEMISKINAN DAN LINGKUNGAN: PERSPEKTIF KEMISKINAN DI PERKOTAAN DAN PEDESAAN. Jurnal Litbang Sukowati: Media Penelitian dan Pengembangan, 5(1), 39-48.

[26]. Prasetyoningrum, A. K., \& Sukmawati, U. S. (2018). Analisis Pengaruh Indeks Pembangunan Manusia (IPM), Pertumbuhan Ekonomi dan Pengagguran Terhadap Kemiskinan di Indonesia. Equilibrium: Jurnal Ekonomi Syariah, 6(2), 217-240. 